\title{
Policy Priorities For Improving The Quality Of Slum Settlements In Banjarmasin City, South Kalimantan Province, Indonesia
}

\author{
Miftahul Chair ${ }^{*}$, Fadly H. Yusran ${ }^{2}$, Husaini ${ }^{3}$, Nasruddin ${ }^{4}$ \\ ${ }^{1}$ Doctoral Program, Agriculture Science, Lambung Mangkurat University, Jl. Jend. A. Yani Km. 36, \\ Banjarbaru, South Kalimantan, 70714, Indonesia, and Department of Investment and Integrated Services \\ Board, South Kalimantan Province, J1. Bangun Praja South Kalimantan Provincial Government Office Areas, \\ Banjarbaru, South Kalimantan, 70733, Indonesia \\ ${ }^{2}$ Department of Soil Science, Faculty of Agriculture, Lambung Mangkurat University, J1. Jend. A. Yani Km. \\ 36, Banjarbaru, South Kalimantan, 70714, Indonesia \\ ${ }^{3}$ Department of Public Health, Faculty of Medical, Lambung Mangkurat University, Jl. Jend. A. Yani Km. 36, \\ Banjarbaru, South Kalimantan, 70714, Indonesia \\ ${ }^{4}$ Department of Geography, Faculty of Social and Political Science, Lambung Mangkurat University, J1. \\ Brigjend. H. Hasan Basri 87, Banjarmasin, 70123, Indonesia
}

Received: November 9, 2020. Revised: March 23, 2021. Accepted: April 7, 2021. Published: April 8, 2021.

\begin{abstract}
Banjarmasin city faces almost the same problems as other big cities in the world, namely slum settlements. One of the factors in the formation of slum settlements in Banjarmasin city is urbanization. The population that continues to increase due to the flow of urbanization causes urban areas to have a very urgent problem, namely the provision of housing facilities. The high price of land in the city center and low-per capita income cause people to tend to look for settlements in suburban areas with inadequate environments and supporting facilities. This research aims to identify the conditions of slum settlements in Banjarmasin City and formulate policy priorities to improve the quality of slum settlements in Banjarmasin City. To answer all these objectives, an integrated settlement management system can be implemented. Comprehensive integration between office holders, stakeholders, and residents will produce a draft policy and slum management scenario. In addition, the policy for sustainable management of slum settlements in Banjarmasin City is also designed using the AHP (Analytical Hierarchy Process) approach. The slum settlements in Banjarmasin city are generally caused by geographical location, where most of them are river and swamp areas. Slums are getting worse because of the bad sanitation system. Ecological factor is the main priority factor in improving the quality of slum settlements. This is because if the slum area is able to maintain its ecology, it will be able to overcome disturbances or pressure, maintain or regain its function and shape. Based on AHP analysis, it is also known that the policy priority in improving the quality of slum settlements is by redevelopment. This effort is the rearrangement of part or all of the area for the purpose of managing the slum settlements in Banjarmasin city.
\end{abstract}

Keywords- Ecology, Poverty, Slums, Regional Development

\section{INTRODUCTION}

Urbanization is a major problem in several cities in developing countries. Urbanization activities are closely related to poverty and environment [1]. In general, the communities living in urban areas are poor, living in housing with infrastructure that is not up to standard conditions. According to [2], urban areas are very vulnerable to change, considering that in the future urban areas will experience a change from slum settlements into a modern city perspective. Slum settlements that cannot adapt to urban planning will be completely vanished from the city. Slum settlements are synonymous with neighborhoods with high population density and are dominated by middle to low income residents [3].

Addressing slum and squatter settlements is something that must be avoided and mistakes are often made, so relevant and successful international experiences need to be studied first. There are three basic stages of international policies regarding slum management, namely eradicating slum areas, site and service policies, and improving the quality of housing and squatters [4]. New housing and community needs are often the big difference in slum eradication, which has been the first approach since the 1950s and 1960s.

The problem of slum settlements is a major challenge for the growth of most cities in developing countries as of today [5][6]. The ability to provide adequate housing and facilities is one solution to the high population density in urban areas. Many people in slum areas live in poor conditions [7], with energy and infrastructure supplies that are not up to standards [8].

Researches with the theme of slum management conducted by academic and professional has been widely discussed. Research conducted by [9] concluded that a settlement area management model with an optimistic scenario in the suburban area of the Jabodetabek Metropolitan City can be applied to a number of areas in Indonesia. Another research conducted by [10], found that participatory collaborative management to improve the community economy in Teluk Leok, Pekanbaru 
City. This is also in line with the research of [11] which found that land readjustment efforts with a participatory intervention approach could be used to convert the Kampong Braga area, Bandung from a heavy slum area into a habitable area.

From several researches on the topic of slum handling that have been mentioned above, it is known that the aspects of the location are important in dealing with slum settlements. [12] stated that the aspects of location, especially hazard-prone locations, slum locations are seen as temporary locations so that there is little attention and improvement to the quality of settlements, so that these slum settlements are always in a negative circle. [13] also explained that the slum management program has an effect on increasing the security of settlements on riverbanks in the Kelayan Area. The availability of basic infrastructure, public facilities, building community capacity, and leadership are factors that influence the success of the settlement security program.

To answer all these challenges, an integrated settlement management system can be implemented. Comprehensive integration between office holders, stakeholders, and residents will produce a draft policy and slum management scenario. In addition, the policy for sustainable management of slum settlements in Banjarmasin city is also designed using the AHP approach. With these several approaches, it is hoped that this research will produce an outcome that will become the basis for improving the quality of these settlements without losing the cultural assets within. In addition, the use of this method is considered to be very effective in solving the ongoing slum settlement problems.

\section{MATERIAL AND METHOD}

\section{A. Place and Time}

This research was conducted in Banjarmasin City, South Kalimantan Province. Astronomically, Banjarmasin City is located at $3^{\circ} 16^{\prime} 46^{\prime \prime}-3^{\circ} 22^{\prime} 54$ " South Latitude and $114^{\circ} 31$ ' 40 " - $114^{\circ} 39^{\prime} 55^{\prime \prime}$ East Longitude. The city of Banjarmasin is located at an average altitude of $0.16 \mathrm{~m}$ below sea level with a relatively flat, marshy area. During high tide, almost the entire area is inundated by water. The research focus is the slum settlement area, which includes five districts namely Central Banjarmasin District, West Banjarmasin District, East Banjarmasin District, North Banjarmasin District and South Banjarmasin District. This research has been conducted for one year, starting from July 2020 to July 2021.

\section{B. Observation and Sampling Methods}

The technique of observation and sampling in this study used purposive sampling method. Based on this explanation, the sample is taken through a representative procedure, which deals with two important aspects, namely accuracy and precision. The sample can be said to be accurate, if the sample statistics can predict population parameters accurately, while the sample can be said to be precise if the sample can reflect the population reality accurately [14]. In this research, there were 25 experts who functioned as informants for stakeholder analysis and preparation of policy directions and implementation strategies, consisting of various backgrounds. In detail, it can be seen in Table 1.

Several bases in determining an expert to be a respondent are : 1) People who are competent or highly knowledgeable, influence policy-making or have a deep understanding of the information required. 2) Has reputation, position and proven expertise in the field of slum management. 3) Has experience in the field of slum management.

\section{Formulating Environmental Management Policies and Scenarios}

The sustainable slum management policy in the Kelayan area was designed using the AHP approach, processed with Expert Choice 11 software. Products in the form of management policy formulations and environmental management scenarios, consisting of the role of stakeholder (determined based on expert judgement), objectives and policy alternatives (determined based on expert judgment and literature review) so that policy recommendations then can be made [15][16]-[18].

\section{RESULTS AND DISCUSSION}

\section{A. The Condition of Slum Settlements in Banjarmasin City}

Slum settlements are settlements that can be physically seen from the shape of its small houses with bad environmental conditions, irregular/uneven settlement patterns, low quality settlements and lack of existing public facilities. The slum indicator can be seen from the lack of basic services available, unfit for habitation houses, high density settlements, unhealthy living conditions and unsafe locations, lack of secure housing rights and poverty [19]-[24].

Slums are an abandoned part of the city where the houses and living conditions are still inadequate. The characteristic of a slum settlement is the condition of being deprived or limited, physically, economically, socially and politically [12]. Physical limitations can be seen from the dense and irregular condition of buildings, the below standard area for proper housing, the lack of basic facilities and infrastructure for settlement such as roads, drainage, clean water and landfill, as well as the locations that are in an unsafe or hazard-prone environment [20]-[24].

In general, slum settlements in Banjarmasin City are caused by the geographical location of the settlements that are in the form of river and swamp areas [18]. These basic physical conditions resulting in a settlement environment that is always inundated by water at high tide. The condition of the settlements that are located on the always watery riverbanks and swamps causes the environment to look slum. Slum is getting worse because of the poor sanitation system both in river and land due to the lack of necessary facilities as well as the accumulated garbage as a result of congestions during high tide [13]. From the results of field observations, it turns out that there are still many residents who bathe, wash and toilet on the latrines along the riverbanks (Figure 1). This condition is exacerbated by the habit to dispose garbage in the river (Figure 2).

The building conditions on the riverbanks is one of the real indicators illustrating that the settlement is unfit for habitation but is still being hold onto. Most of these settlements are inhabited by low-income groups of people. The following shows the conditions settlements in several areas such as Pelambuan Sub-District (Figure 3) and Pekapuran Raya SubDistrict (Figure 4). Most of the settlement conditions in the Banjarmasin City area are included in the light slum category 
as stated in the data from the Banjarmasin City Housing and Settlement Service in 2020.

\section{B. Analysis of Slum Management Policies in Banjarmasin City}

Analysis of slum management policies in Banjarmasin City was performed using the AHP method, by taking into account the factors that influence and the objectives to be achieved, a hierarchical structure consisting of 4 (four) levels can be arranged [18] as presented in Figure 5.

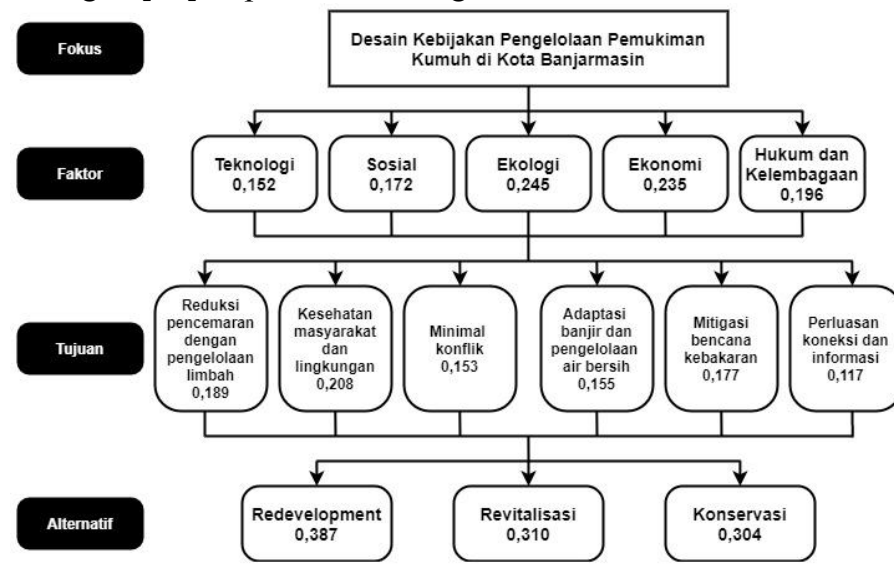

Figure 1. AHP Hierarchy Diagram of Slum Management Policies in Banjarmasin City

AHP results at the first level are the focus or goal which is the core of the problem to be solved [17]. The second level is the factors formulating the strategy consisting of technology, social, ecological, economic as well as legal and institutional. The third level is the goals to be achieved from the implementation of the strategy, which consists of 6 (six) objectives. The fourth level as the last level is an alternative to things that are formulated as a recommendation of the results of the research objectives, which consist of redevelopment, revitalization and conversion.

Based on the calculation of priority values for each level of AHP, the following results are obtained:

a. Supporting Factors

There are 5 supporting factors in making the slum management decisions in Banjarmasin City. The importance of supporting factors in determining policy alternatives is presented in Table 2.

From Table 2 it is known that the priority value of ecological and economic factors in determining policy alternatives are the most determining factors $(0.245$ and 0.235$)$. This shows that ecological and economic factors are the most important factors in slum management. The results of these calculations affect the next stages of decision making.

The increasing number of residents in the city center causes the need for habitable housing to be quite high. Especially for urban communities whose livelihoods are concentrated in the trade and services sector in the city center [25]-[28]. From an ecological aspect, slum areas will have an impact as a factor in the quality degradation that occurs in their environment, for example, this area is a disaster-prone area, especially to floods and fires. This is due to the relatively high building density, localization of used goods collectors, and the absence of green open spaces (RTH) as rainwater infiltration areas. Public health aspects such as those that are susceptible to disease risk are affected by a decrease in environmental quality as a result of environmental damage itself [29]-[31]. Economic factors are the second largest priority value after ecological factors in policy considerations. The causes of slums in a settlement area are low socio-economic conditions and high population density [6], [7], [32]-[34].

\section{b. Management Objectives}

There are 6 management objectives in making slum management decisions in Banjarmasin City. From Table 3, it is known that the main priority value of management objectives is public and environmental health with a value of 0.208 . The second priority is reducing pollution by managing waste with a value of 0.189 . The third priority is minimal conflict with a value of 0.153 , the fourth priority is flood adaptation and clean water management with a value of 0.155 , the fifth priority is fire disaster mitigation with a value of 0.177 , and the sixth priority is expansion of connections and information with a value of 0.117 . Management objectives in determining policy alternatives are presented as Table 3

c. Hierarchy of Policy Alternatives Based on Management Objectives

From Table 4, it is known that the main policy alternative is redevelopment, which is an effort to rearrange part or all of the area as a priority strategy for all slum management objectives in the city of Banjarmasin. Through redevelopment, it is hoped that the rearrangement of slum settlement areas in the city of Banjarmasin will be adjusted to the priority objectives of slum management.

The restructuring of the slum settlements was followed by the provision of public facilities such as health facilities, educational facilities, religious facilities, trade facilities and public open spaces. Settlement arrangement can be carried out on buildings, building density levels, and building technical requirements [35]-[37]. Buildings in a detailed spatial plan can be reviewed based on the shape, size, placement and appearance of the building while the buildings in the building and environmental plan include the settings of environmental block, plot, floor height and elevation, environmental identity concept, orientation concept and the face of the road [25], [26], [38].

\section{Safe and Comfortable Settlement Area Structuring} Strategy by Implementing the RTRW of Banjarmasin City

The strategy in the RTRW of Banjarmasin City in an effort to arrange settlements is inseparable from other spatial/area planning policies that are also regulated in the RTRW. The achievement between land cover suitability and the application of the RTRW for Banjarmasin City has a very good percentage. In 2014, 2017 and 2019 the suitability of land cover with RTRW are $95 \%, 92.17 \%$ and $92.52 \%$, respectively. The map of land cover by settlements in 2019 which amounted to $52.63 \%$ and the map of land cover suitability in 2019 which amounted to $92.52 \%$ show the success of the RTRW strategy in overcoming slum settlements. This is indicated by the 549 ha area of slum settlements that have been successfully relocated by the Banjarmasin City government until 2019 amounted to 
78.69\%. Many physical activities aimed at slum reduction are concrete actions and seriousness in reducing and handling slum areas in Banjarmasin City. The recap of the calculation results of slum reduction in Banjarmasin City can be seen in Table 5.

The Department of Housing and Settlements Area of Banjarmasin City in conducting settlement area arrangement always makes efforts to maintain the local physical and cultural characteristics. Maintaining physical and cultural characteristics is carried out by preserving the existing built-in landscape formation so that it does not experience change, returning settlement patterns and orientation, as it was in the past. To organize a settlement, the elements in the settlement must be considered. According to experts, the elements forming the settlement are interrelated and influence each other. Those elements are nature, humans, community life, shelter as well as settlement facilities and infrastructure [2], [5], [11], [12], [36], [39]-[42].

The structuring plan for the slum settlement area in order to maintain the physical and cultural characteristics is carried out by preserving the existing built-in landscape formation so that it does not experience change. Therefore, the houses that are located above the river body are partially preserved because they are part of the culture of this settlement. Houses above the river body are selected with special considerations, namely the age of buildings over 50 years. Houses less than 50 years old had to be relocated. Settlement expansion that leads to the river body must be stopped to prevent building overcrowding and to eliminate the impression of slums [5], [11], [12], [36], [39].

Another action in structuring this settlement is returning settlement patterns and orientation to the way it was. This means that houses that are located on the river body will have two faces, one facing the road and one facing the river [43]. This is because houses that are above the river body are generally oriented towards the road so that the river is behind them. This can be seen from the concepts that have been made in the Kelayan Pekauman Area (Figure 6) and the Kuin Alalak Area (Figure 7).

\section{CONCLUSION}

Slum settlements in Banjarmasin are scattered around the city of Banjarmasin. In general, these slum settlements are caused by the geographical location of the settlements, where most of them are river and swamp areas. Slum settlements are getting worse because of poor sanitation systems. Five factors that influence slum management provide alternatives to choose from. Ecological factor is the main priority factor in slum management because if the slum area is able to maintain its ecology, it will be able to overcome disturbances or pressure, maintain or regain its function and shape. Based on the AHP analysis, it is known that the main policy alternative is redevelopment, which is an effort to rearrange part or all of the area as a priority strategy for all slum management objectives in the city of Banjarmasin. Through redevelopment, it is hoped that the rearrangement of slum settlement areas in the city of Banjarmasin will be adjusted to the priority objectives of slum management.

\section{ACKNOWLEDGEMENTS}

This study was supported by all authors / co-authors registered for approval during the study, data analysis and interpretation, and revision of the manuscript. This research aims to improve knowledge during doctoral education. This research did not get financial assistance from any party.

\section{REFERENCES}

[1] H. R. Adisasmita, Pembangunan Ekonomi Perkotaan. Yogyakarta: Graha Ilmu, 2005.

[2] B. Setiawan, Kampung Kota dan Kota Kampung, Potret Tujuh Kampung di Kota Jogja [Urban Village and Slum City, Portrait of Seven Urban Villages in Yogyakarta]. Yogyakarta: Pusat Studi Lingkungan Hidup, Universitas Gadjah Mada, 2010.

[3] M. V. Michiani and J. Asano, "Physical upgrading plan for slum riverside settlement in traditional area: A case study in Kuin Utara, Banjarmasin, Indonesia," Frontiers of Architectural Research, vol. 8, no. 3, pp. 378-395, 2019, doi: 10.1016/j.foar.2019.03.005.

[4] A. D. Slaev, "Bulgarian policies Towards The Roma Housing Problem And Roma Squatter Settlements," Eur. J. Hous. Policy, vol. 7, no. 7, pp. 63-84, 2007.

[5] S. Nakamura, "Impact of slum formalization on self-help housing construction: A case of slum notification in India," Urban Studies, vol. 51, no. 16, pp. 3420-3444, 2014, doi: 10.1177/0042098013519139.

[6] D. Roy and M. Lees, "Understanding resilience in slums using an agent-based model," Computers, Environment and Urban Systems, vol. 80, no. January, p. 101458, 2020, doi: 10.1016/j.compenvurbsys.2019.101458.

[7] O. S. Badmos, A. Rienow, D. Callo-Concha, K. Greve, and C. Jürgens, "Simulating slum growth in Lagos: An integration of rule based and empirical based model," Computers, Environment and Urban Systems, vol. 77, no. July, p. 101369, 2019, doi: 10.1016/j.compenvurbsys.2019.101369.

[8] J. Friesen, H. Taubenböck, M. Wurm, and P. F. Pelz, "The similar size of slums," Habitat International, vol. 73, no. February, pp. 79-88, 2018, doi: 10.1016/j.habitatint.2018.02.002.

[9] J. T. Hidajat, "Model Pengelolaan Kawasan Permukiman Berkelanjutan di Pinggiran Kota Metropolitan Jabodetabek," Institut Pertanian Bogor, Bogor, 2014.

[10] Z. Rachman, "Rancangan Pengelolaan Perbaikan Permukiman Kumuh Teluk Leok Di Kota Pekanbaru," Institut Pertanian Bogor, Bogor, 2004.

[11] H. Nisa, "Studi Vitality Kota Sebagai Dasar Revitalisasi Kota Banjarmasin Kalimantan Selatan Berbasis Waterfront City," nstitut Pertanian Bogor, Bogor, 2017.

[12] K. Olthuis, B. J, E. K, and Z. C, "Slum Upgrading: Assessing the importance of location and a plea for a spatial approach," Habitat International, vol. 50, pp. 270-288, 2015.

[13] Y. Dahliani, "Pengaruh Program Penanganan Permukiman Kumuh Terhadap Ketahanan Permukiman Tepian Sungai Kota Banjarmasin," Universitas Gadjah Mada, Yogyakarta, 2018.

[14] H. Usman and P. S. Akbar, Metodologi Penelitian Sosial. Jakarta: Bumi Aksara, 2014.

[15] T. Saaty, Pengambilan Keputusan bagi Para Pemimpin: Proses Hirarki Analitik untuk pengambilan Keputusan dalam Situasi yang Kompleks. Jakarta: PT Pustaka Binaman Pressindo, 1993. 
[16] D. Novian, "Sistem Pendukung Keputusan Mutasi, Enumerasi, dan Promosi Pegawai Menggunakan Metode AHP (Analitic Hierarchy Process)," Media Elektrik, vol. 5, no. 2, 2010.

[17] Marsono, Penggunaan Metode Analytical Hierarchy Process (AHP) dalam Penelitian. Bogor: In Media, 2020.

[18] A. S. Wimardana, "Faktor Prioritas Penyebab Kumuh Kawasan Permukiman Kumuh Di Kelurahan Belitung Selatan Kota Banjarmasin," Jurnal Teknik ITS, vol. 5, no. 2, 2016, doi: 10.12962/j23373539.v5i2.18386.

[19] A. Das, "Slum upgrading with community-managed microfinance: Towards progressive planning in Indonesia," Habitat International, vol. 47, pp. 256-266, 2015, doi: 10.1016/j.habitatint.2015.01.004.

[20] J. Yu, H. Shannon, A. Baumann, L. Schwartz, and M. Bhatt, "Slum Upgrading Programs and Disaster Resilience: A Case Study of an Indian 'Smart City,"' Procedia Environmental Sciences, vol. 36, pp. 154-161, 2016, doi: 10.1016/j.proenv.2016.09.026.

[21] J. Minnery et al., "Slum upgrading and urban governance: Case studies in three South East Asian cities," Habitat International, vol. 39, pp. 162-169, 2013, doi: 10.1016/j.habitatint.2012.12.002.

[22] D. Muchadenyika, "Slum upgrading and inclusive municipal governance in Harare, Zimbabwe: New perspectives for the urban poor," Habitat International, vol. 48, pp. 1-10, 2015, doi: 10.1016/j.habitatint.2015.03.003.

[23] A. Krishna, M. S. Sriram, and P. Prakash, "Slum types and adaptation strategies: identifying policy-relevant differences in Bangalore," Environment and Urbanization, vol. 26, no. 2, pp. 568-585, 2014, doi: $10.1177 / 0956247814537958$.

[24] K. Patel, "A successful slum upgrade in Durban: A case of formal change andinformal continuity," Habitat International, vol. 40, pp. 211-217, 2013, doi: 10.1016/j.habitatint.2013.05.005.

[25] UN-Habitat, "Urban National Urban Profile." UNHabitat, Nairobi, 2012.

[26] UN-Habitat, "Affordable Land and Housing in Asia." UN-Habitat, Nairobi, 2011.

[27] UN-Habitat, "Citywide Strategic Planning: A Step by Step Guide." UN-Habitat, Nairobi, 2010.

[28] UN-Habitat, "Secure Land Right for All." UN-Habitat, Nairobi, 2008.

[29] N. Annisa, R. Riduan, and H. Prasetia, "Aplikasi Rain Garden Untuk Memperindah Dan Meningkatkan Kualitas Lingkungan Kota," Jukung Jurnal Teknik Lingkungan, vol. 2, no. 2, pp. 22-37, 2016.

[30] N. Annisa, R. Riduan, and H. Prasetia, "Model Rain Garden Untuk Penanggulangan Limpasan Air," vol. 2, no. 1, pp. 78-92, 2016.

[31] H. Prasetia, N. Harijati, and N. Annisa, Rain Garden. Malang: CV IRDH, 2018.

[32] Z. Bah, E., Faye, I., F Geh, "Slum Upgrading And Housing Alternatives For The Poor," Housing Market Dynamics in Africa, pp. 215-253, 2018.

[33] R. Debnath, R. Bardhan, and M. Sunikka-Blank, "How does slum rehabilitation influence appliance ownership? A structural model of non-income drivers," Energy
Policy, vol. 132, no. May, pp. 418-428, 2019, doi: 10.1016/j.enpol.2019.06.005.

[34] A. A. Pedro and A. P. Queiroz, "Slum: Comparing municipal and census basemaps," Habitat International, vol. 83, no. October 2018, pp. 30-40, 2019, doi: 10.1016/j.habitatint.2018.11.001.

[35] L. Muta'ali and A. R. Nugroho, Perkembangan Program Penanganan Permukiman Kumuh di Indonesia dari Masa ke Masa. Yogyakarta: Gadjah Mada University Press, 2016.

[36] L. Muta'ali, Penataan Ruang Wilayah dan Kota. Yogyakarta: Badan Penerbit Fakultas Geografi (BPFG) Universitas Gadjah Mada, 2013.

[37] L. Muta'ali, Teknik Analisis Regional untuk Perencanaan Wilayah, Tata Ruang dan Lingkungan. Yogyakarta: Badan Penerbit Fakultas Geografi (BPFG) Universitas Gadjah Mada, 2015.

[38] D. Muchadenyika and J. Waiswa, "Policy, politics and leadership in slum upgrading: A comparative analysis of Harare and Kampala," Cities, vol. 82, no. May, pp. 5867, 2018, doi: 10.1016/j.cities.2018.05.005.

[39] A. A. Daniel, M.M., Wapwera, S.D., Akande, E.M., Musa, C.C., Aliyu, "Slum Housing Conditions And Eradication Practices In Some Selected Nigerian Cities," J. Sustain. Dev, vol. 8, no. 2, pp. 230-241, 2015.

[40] B. T. Soegijoko, Metropolitan di Indonesia : Kenyataan dan Tantangan dalam Penataan Ruang. Direktorat Penataan Ruang, 2006.

[41] K. P. Dewi, V. A. Kumurur, and R. L. E. Sela, "Penentuan Kualitas Permukiman Berdasarkan Kriteria Ecosettlement di Kelurahan Sindulang Satu Kota Manado," Jurnal Spasial, vol. 6, no. 1, pp. 169-177, 2019.

[42] S. Togubu, F. Warouw, and R. Ch. Tarore, "Strategi Revitalisasi Kawasan Permukiman Kumuh di Kelurahan Calaca Kota Manado," Sabua, vol. 6, no. 2, pp. 223-234, 2014.

[43] Dinas Perumahan dan Kawasan Permukiman Kota Banjarmasin, "Luasan KUMUH Kota Banjarmasin Tahun 2020.

Creative Commons Attribution License 4.0 (Attribution 4.0 International, CM3 BY 4.0)

This article is published under the terms of the Creative Commons Attribution License 4.0

https://creativecommons.org/licenses/by/4.0/deed.en_US 


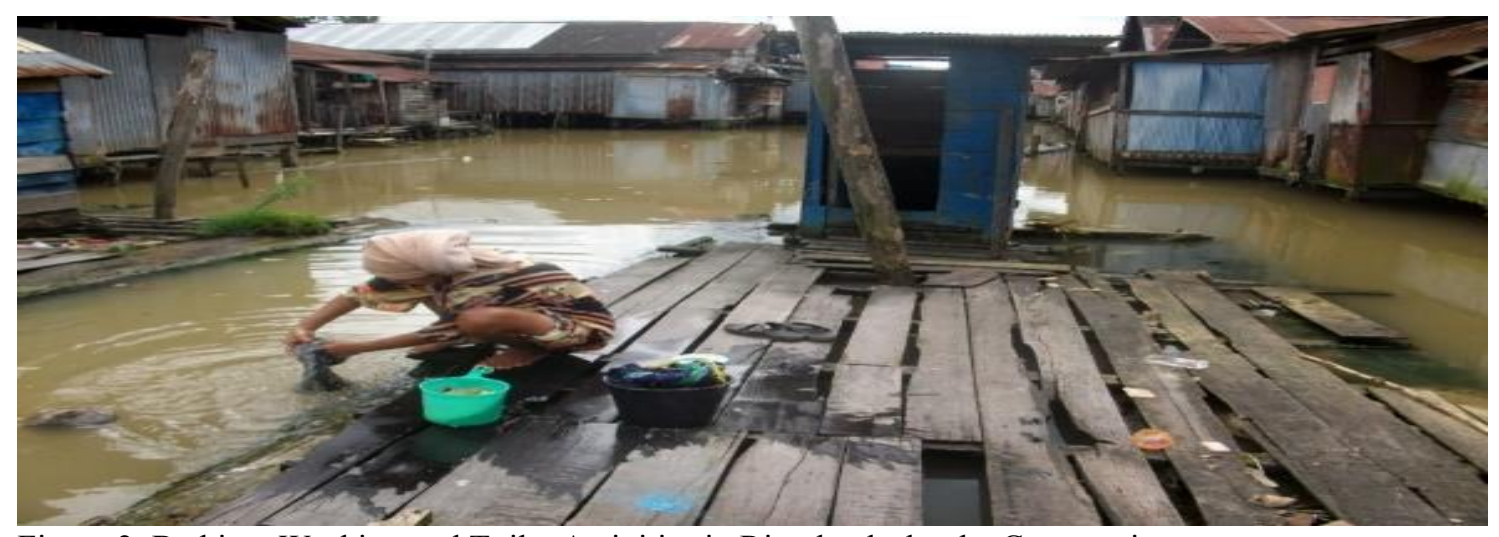

Figure 2. Bathing, Washing and Toilet Activities in Riverbanks by the Community

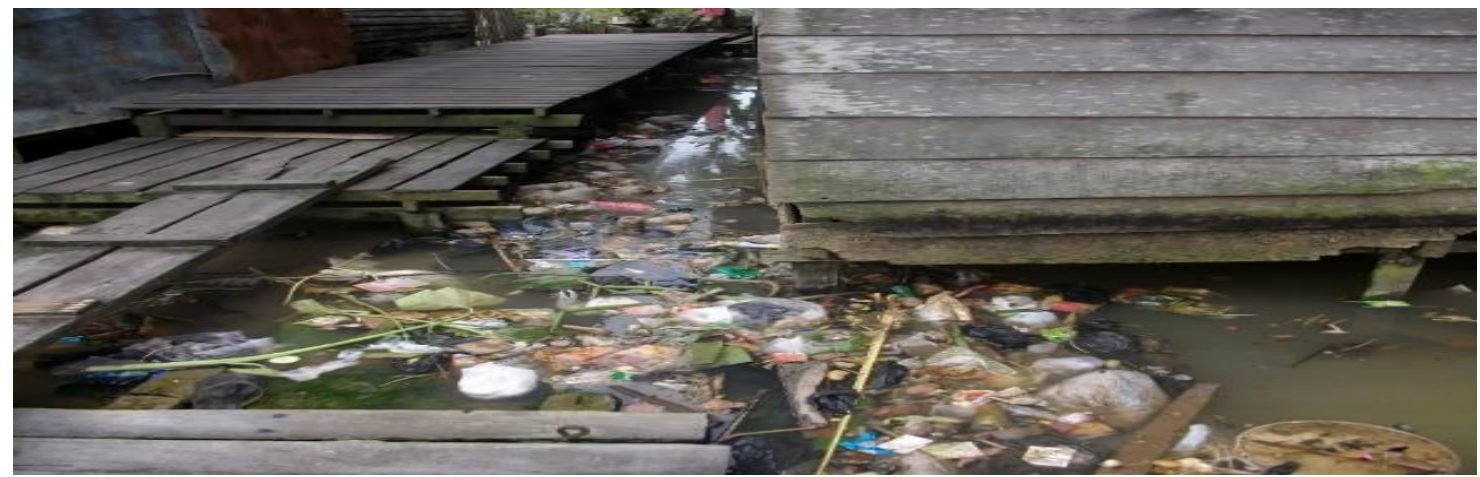

Figure 3. Activities to Dispose of Garbage in the River by the Community

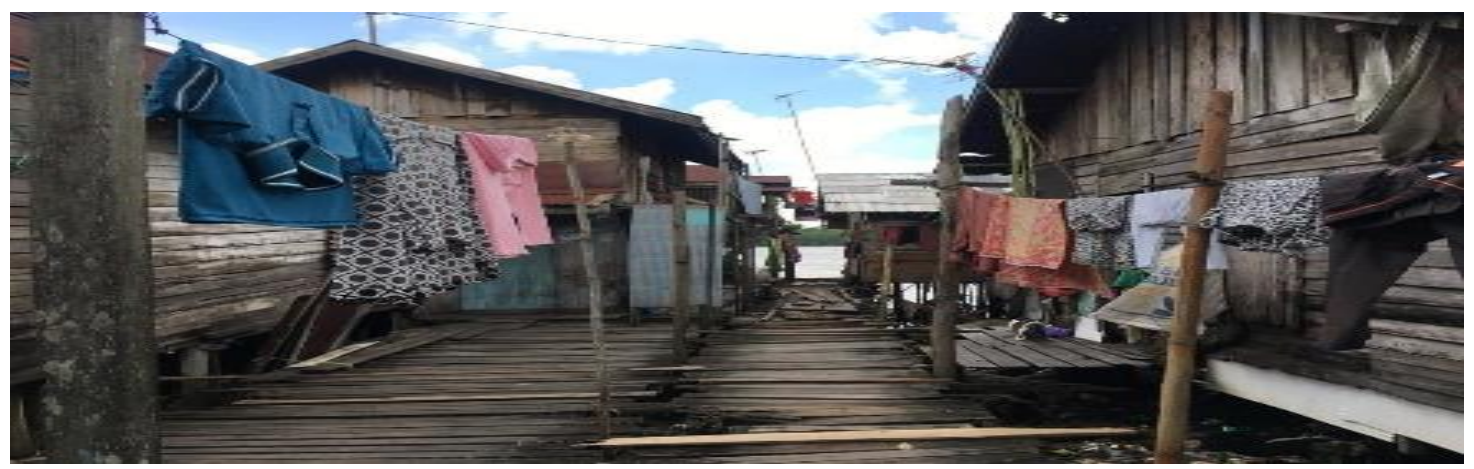

Figure 4. Slum Settlements in West Banjarmasin District (Pelambuan Sub-District)

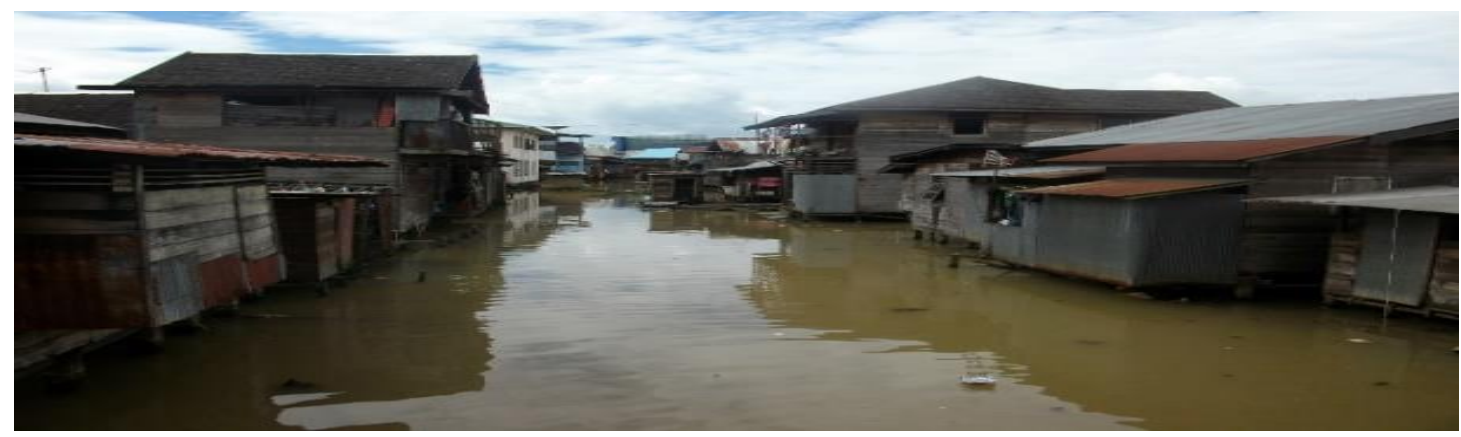

Figure 5. Slum Settlements in East Banjarmasin District (Pekapuran Raya Sub-District) 


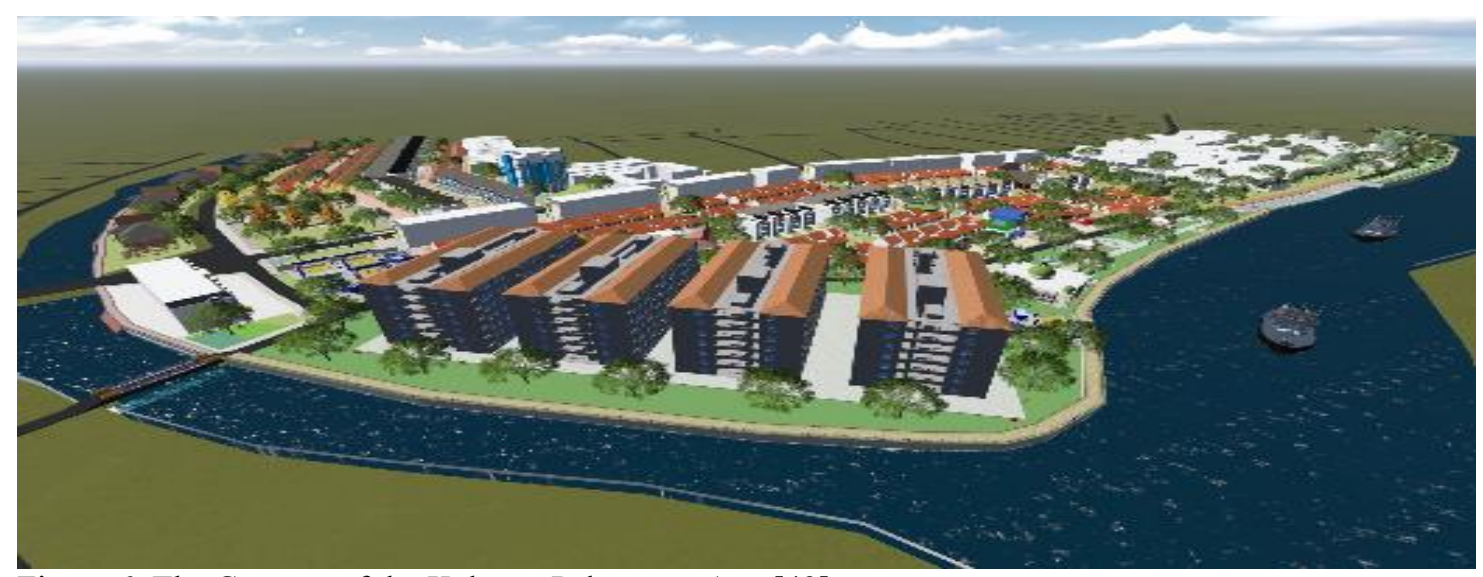

Figure 6. The Concept of the Kelayan Pekauman Area[43]

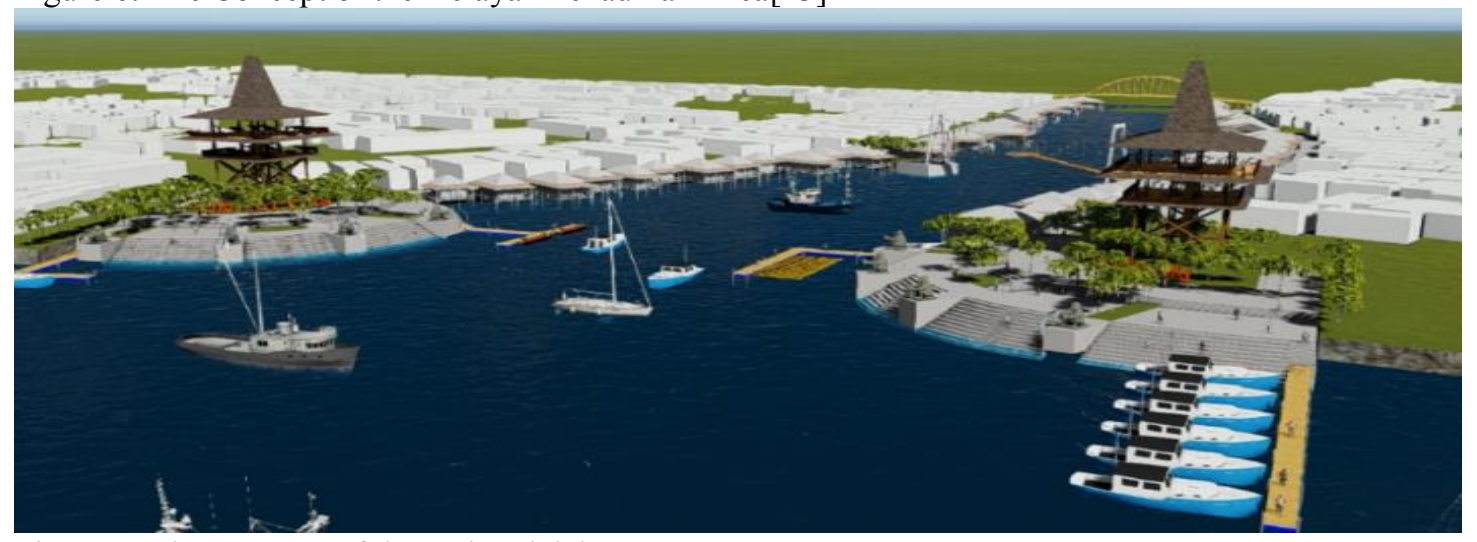

Figure 7. The Concept of the Kuin Alalak Area

(The Department of Housing and Settlements Area of Banjarmasin City, 2020)

Table 1. The number of experts involved in the research

\begin{tabular}{llc}
\hline No & \multicolumn{1}{c}{ Classification } & Total \\
\hline 1. & Competent Lecturers in the respective fields & 6 \\
2. & $\begin{array}{l}\text { Bureaucracy (Head of Public Works, District Head (5 District), Head of Environmental } \\
\text { Administration, Head of Regional Development Planning Agency, Licensing Department) }\end{array}$ & 10 \\
3. & $\begin{array}{l}\text { Non-Governmental Organization } \\
\text { 4. }\end{array} \quad$ Community Leaders (Business Actors, Banks, Traditional Leaders (5 Districts)) & 2 \\
\hline & \multicolumn{1}{c}{ Total Sample } & 7 \\
\hline
\end{tabular}

Table 2. $\quad$ Priority of Supporting Factors Based on the Level of Importance in Slum Management in Banjarmasin City

\begin{tabular}{|c|c|c|}
\hline No. & Supporting Factors & Priority Value \\
\hline 1 & Technology & 0,152 \\
\hline 2 & Social & 0,172 \\
\hline 3 & Ecology & 0,245 \\
\hline 4 & Economy & 0,235 \\
\hline 5 & Legal and Institutional & 0,196 \\
\hline
\end{tabular}

Inconsistency $=0.03$

Table 3.Management Objectives Priority in Slum Settlement Management in Banjarmasin City

\begin{tabular}{clc}
\hline No. & \multicolumn{1}{c}{ Management Objectives } & Priority Value \\
\hline 1 & Reduction of pollution by waste management & 0,189 \\
2 & Public and environmental health & 0,208 \\
3 & Minimal conflict & 0,153 \\
4 & Flood adaptation and clean water management & 0,155 \\
5 & Fire disaster mitigation & 0,177 \\
6 & Expansion of connections and information & 0,117 \\
\hline
\end{tabular}


Table 4.Hierarchy of Alternative Slum Management Policies in Banjarmasin City

\begin{tabular}{|c|c|c|c|c|c|c|c|c|}
\hline \multirow[b]{2}{*}{ No. } & \multirow[b]{2}{*}{ Alternative Policies } & \multicolumn{6}{|c|}{ Management Objectives } & \multirow[t]{2}{*}{ Global Priority } \\
\hline & & 1 & 2 & 3 & 4 & 5 & 6 & \\
\hline 1 & Redc & $0,426^{*}$ & $0,375^{*}$ & $0,352^{*}$ & $0,363^{*}$ & $0,407^{*}$ & $0,404^{*}$ & $0,387^{*}$ \\
\hline 2 & Revitalization & 0,250 & 0,324 & 0,324 & 0,314 & 0,321 & 0,329 & 0,310 \\
\hline 3 & Conservation & 0,324 & 0,301 & 0,324 & 0,322 & 0,272 & 0,266 & 0,304 \\
\hline
\end{tabular}

Objectives: (1) Reduction of pollution by waste management; (2) Public and environmental health; (3) Minimal conflict; (4) Flood adaptation and clean water management; (5) Fire disaster mitigation; (6) Expansion of connections and information

Table 5. The Calculation Results of Slum Reduction in Banjarmasin City

\begin{tabular}{|c|c|c|c|c|c|c|c|c|c|}
\hline $\begin{array}{c}\text { Sub- } \\
\text { District }\end{array}$ & $\begin{array}{l}\text { Ha of } \\
\text { Slum } \\
\text { SK } \\
2015\end{array}$ & $\begin{array}{c}\text { Ha of Slum } \\
\text { Manageme } \\
\text { nt } 2016\end{array}$ & $\begin{array}{c}\text { Ha of } \\
\text { Remainin } \\
\text { g Slum } \\
2016\end{array}$ & $\begin{array}{c}\text { Ha } \\
\text { Of Slum } \\
\text { Manageme } \\
\text { nt } \\
2017 \\
\end{array}$ & $\begin{array}{c}\text { Ha of } \\
\text { Remainin } \\
\text { g Slum } \\
2017\end{array}$ & $\begin{array}{c}\text { Ha of Slum } \\
\text { Manageme } \\
\text { nt } 2018\end{array}$ & $\begin{array}{c}\text { Ha of } \\
\text { Remainin } \\
\text { g Slum } \\
2018\end{array}$ & $\begin{array}{c}\text { Ha of Slum } \\
\text { Manageme } \\
\text { nt } 2019\end{array}$ & $\begin{array}{c}\text { Ha of } \\
\text { Remainin } \\
\text { g Slum } \\
2019\end{array}$ \\
\hline $\begin{array}{l}\text { North } \\
\text { Banjarmasi } \\
n\end{array}$ & 137.21 & 27.06 & 110.15 & 8.71 & 101.44 & 63.47 & 37.97 & 18.55 & 19.42 \\
\hline $\begin{array}{l}\text { West } \\
\text { Banjarmasi } \\
\mathrm{n}\end{array}$ & 56.83 & 2.97 & 53.86 & 5.58 & 48.28 & 38.27 & 10.01 & 9.47 & 0.54 \\
\hline $\begin{array}{l}\text { South } \\
\text { Banjarmasi } \\
n\end{array}$ & 220.36 & 43.88 & 176.48 & 21.96 & 154.52 & 116.71 & 37.81 & 23.83 & 13.98 \\
\hline $\begin{array}{l}\text { Banjarmasi } \\
\text { n City }\end{array}$ & 549.7 & 90.32 & 459.38 & 62.49 & 396.89 & 279.06 & 117.83 & 71.62 & 46.21 \\
\hline Total & $\begin{array}{c}100.00 \\
\%\end{array}$ & $16.43 \%$ & $83.57 \%$ & $11.37 \%$ & $72.20 \%$ & $50.77 \%$ & $21.44 \%$ & $13.03 \%$ & $8.41 \%$ \\
\hline
\end{tabular}

Source: The Department of Housing and Settlements Area of Banjarmasin City (2020) 